\title{
Estimation of Superiority Percentage and Combining Ability of Grain Yield and Some Other Traits in Yellow Maize
}

\author{
H.A. Aboyousef \\ Maize Research Section, Field Crops Research Institute, ARC, Egypt.
}

\begin{abstract}
Seventeen yellow inbred lines of maize were crossed with two yellow inbred testers Gm1002 and Gm 1021 to produce 38 hybrids during summer of 2016 at Gemmeiza research station. In summer seasons of 2017 the 38 hybrids and two checks were evaluated at two locations; Gemmeiza and sids research stations. The rustles of these studies might be summarized as follows, locations mean square were highly significant for all studied traits under combined data. The additive and additive $\mathrm{x}$ additive gene actions played more important role in the inheritance of for plant height and ear length from combined data, while, the non- additive gene action was more important for days to $50 \%$ silking, ear height, ear diameter and grain yield at Gemmeiza, Sids and the combined analysis. The results indicated that grain yield for inbred lines (Gm 23, 45, 46 and 53) had desirable positive and significant GCA ( $\left.\mathrm{g}^{\wedge} \mathrm{i}\right)$. Two crosses namely (Gm $24 \mathrm{x}$ Gm 1021) (36.5 ard./fed.) and (Gm 46x Gm 1021) (35.4 ard./fed.) had desirable significant superiority percentage for grain yield compared with the best check hybrid, Sc 168 (32.1 ard./ fed.).
\end{abstract}

Key words: (Zea mays L.), Top cross, combining ability, Genotype $\mathbf{x}$ environment, Yellow Maize.

\section{INTRODUCTION}

Maize is one of the most important cereal crops and occupies a prominent position in global agriculture after wheat and rice. Among cereals, maize is rich in starch, proteins, oil and sucrose, due to which it has assumed significant industrial importance. The main goal of maize breeding is to obtain new hybrids with high genetic potential for yield and positive features that exceed the existing commercial hybrids. The commercial production of hybrids, however, depends upon two factors viz; the behavior of the line itself and the behavior of this line in hybrid combinations. The behavior of a line in hybrid combination is assessed through the estimation of general combining ability (gca) and specific combining ability (sca) effects. Combining ability analysis is an important method to evaluate the prepotency of cultures to be used in breeding programmer and to assess the gene action involved in various characters, so as, to design an appropriate and efficient breeding method. Combining ability analysis provides this information and is frequently used by plant breeders to choose parents with a high general combining ability and hybrids with high specific combining ability effects. Numerous investigators reported that the additive gene effects played an effective role in the inheritance of grain yield (Paul and Debanth, 1999; Irshad-El-Haq et al., (2010) and El-Badawy (2013) and number of rows/ear (Mosa et al., 2009; Mosa, 2010 and Aly et al., 2011). While, Kamara (2012), Aly (2013), ElBadawy (2013) and EL-Hosary and Elgammaal (2013) showed that, the non-additive gene effects represented the major role in the inheritance of grain yield and other agronomic traits. Line $\mathrm{X}$ tester analysis is an extension of the top cross method in which several testers are used (Kempthorne,1957). The main objectives of this study are; (a) estimate combining ability of inbred lines for grain yield and other agronomic traits (b) identify the type of gen action that play an effective role in the inheritance of studied traits and (c) identify the superior crosses with yielding ability in the maize breeding program.

\section{MATERIAL AND METHODS}

Seventeen yellow maize inbred lines; (Gm 23, $24,25,26,28,43,45,46,48,52,53,54,55,59$, 62, 63 and 64) were crossed with two yellow inbred testers Gm1002 and Gm 1021 (name and origin of lines and testers was presented in Table 1) in line $\mathrm{x}$ tester fashion to produce 38 hybrids during summer of 2016 at Gemmeiza research station.

Table 1: Name and origin of seventeen yellow inbred lines and two yellow inbred testers.

\begin{tabular}{ll}
\hline Lines & Origin \\
\hline Gm 23,24,25,26,28,43,45,46,48,52,53,54 and 55 & Nubaria yellow Pop. \\
\hline Gm 59,62,63 and 64 & (Comp.\# 21) \\
\hline Testers & Origin \\
\hline Gm1002 & $\begin{array}{l}\text { Sub-tropical yellow maize pop (DMR) imported } \\
\text { from IITA Nigeria. }\end{array}$ \\
\hline Gm 1021 & Sd 121 x pop. (DMR - ESR) yellow. \\
\hline
\end{tabular}


The $34 \mathrm{~F}_{1}$ hybrids with two standard check hybrids i.e; SC. 162 and SC.168 were evaluated in randomized block design with four replications during summer of 2017 in two experimental farms of Gemmeiza and Sids research stations. Each entry comprised of one rows having 25 plants per row in each replication in a plot size of $4.8 \mathrm{~m}^{2}$. The data were recorded for six quantitative characters namely, days to $50 \%$ silking, plant height, ear height, ear length, ear diameter and grain yield (ard. / fed.). Line x Tester analysis was carried out as described by Kempthorne (1957). The superiority percentage was estimated over the two checks as per standard procedure.

\section{RESULTS AND DISCUSSION}

\section{1-Analysis of variance:}

Mean squares results for six traits (days to $50 \%$ silking, plant height, ear height, ear length, ear diameter and grain yield) at the two locations and combined data were presented in Table 2. Locations mean square was highly significant for all studied traits, indicating, different environmental conditions at the two locations. These results were in agreement with those obtained by. Ibrahim et al. (2007) and Darwich et al. (2016). Mean squares of crosses and their partitions (lines, testers and lines $\mathrm{x}$ testers) were highly significant for all studied traits, except, crosses and line $\mathrm{x}$ tester mean squares for ear length and ear diameter at the two locations and combined data. Mean squares for ear length were insignificant for only lines and testers at Sids and also were insignificant for ear diameter at both locations. That was in harmony with combined analysis. These results were in line with those obtained by Sadek et al. (2001), Gamea et al. (2015) and Aboyousef et al. (2016). On the other hand, highly significant differences were detected for crosses $\mathrm{x}$ locations interaction for plant height, ear height and grain yield indicating variable response of crosses to environment. Line $\mathrm{x}$ location mean squares were highly significant for plant height, ear height and grain yield indicating that line varied in magnitude of character with different locations. while, tester $\mathrm{x}$ location exhibited significant effect for days to $50 \%$ silking, ear height and grain yield, meaning that, testers were affected by change from one locations to another for these traits (Mosa, 2010 and Aly et al., 2011).

\section{2- Mean performance}

Data in Table (3) showed the mean performance of thirty four crosses and two checks for days to $50 \%$, plant height, ear height, ear length, ear diameter and grain yield traits over two locations and combined data. Number of days to $50 \%$ silking, showed that, three crosses at Gemmeiza location and all crosses at Sids location and over combined date, showed significantly for earliness, compared to the earliest check hybrid SC.166. As for, ear length, none of the evaluated crossed significantly surpassed the check hybrids with the tallest ear for SC.162. Regarding ear diameter, only (Gm. $23 \mathrm{x}$ Gm. 1002) and (Gm. 45 x Gm. 1021) crosses significant gave lower ear diameter compared with the check SC.168, which, had the least ear diameter $(5.1 \mathrm{~cm})$ at Gemmeiza location only. Grain yield at Gemmeiza location for crosses and checks ranged from 20.7 to 41.8 ard. / fed. Only the cross (Gm 24 $\mathrm{x}$ Gm 1021) produced the highest grain yield (41.8 ard./fed.) that significantly out-yielded the highest yielding check.

Only at Sids location (Gm46 x Gm 1021) cross (33.4 ard. /fed.) Significantly out- yielded the best check SC168 (29.8 ard. /fed.).

Values of combined data for grain yield ranged from (21.9 ard. / fed) for cross Gm46 x Gm1002 to 36.5 ard. / fed. for cross Gm24 x Gm1021. Two crosses i.e. (Gm24 x Gm1021) 36.5 ard. / fad. and Gm 46x Gm 1021 (35.4 ard./fed.) significantly out yielded the best checks, SC 168.

\section{Gene action}

Estimation of genetic parameters for the six traits were shown as combined data in Table (4). Results in this Table cleared that, $\sigma^{2}$ GCA-L was more than $\sigma^{2}$ GCA xT for plant height and grain yield at Sids location and in combined data. Also, ear length and ear diameter at the two locations and combined date matched true. Days to $50 \%$ silking and ear height at Sids location had such significant interactions, meaning that most of additive gene action was due to lines, while, in the other traits most of additive gene action was due to testers. These results in harmony with those reported by Aly et al. (2011), Mousa and Aly (2012) and Aly (2013). The additive and additive $\mathrm{x}$ additive gene actions played more importance in the inheritance of plant height and ear length from combined data, while, the non- additive gene actions was important in the inheritance of days to $50 \%$ silking, ear height, ear diameter and grain yield at Gemmeiza, Sids or from the combined data. These results was in harmony with those reported by Singh and Roy (2007) and Aboyousef et al.(2016). The ratio $\sigma^{2}$ GCA x Loc / $\sigma^{2}$ SCA $x$ Loc was less than unity for plant and ear heights and grain yield, indicating that non- additive gene effects played an important role with change in environments. Aly (2013) found that, the interaction of $\sigma^{2}$ SCA $x$ location was higher than those $\sigma^{2}$ GCA $x$ location for plant and ear heights, and grain yield. On the other side, the same ratio was more than unity for; days to $50 \%$ silking, ear length and ear diameter traits, meaning that, additive genes were more important than non- additive with change in locations. Barakat et al. (2003) found that, the non additive gene effects were interacted with locations for grain yield. 


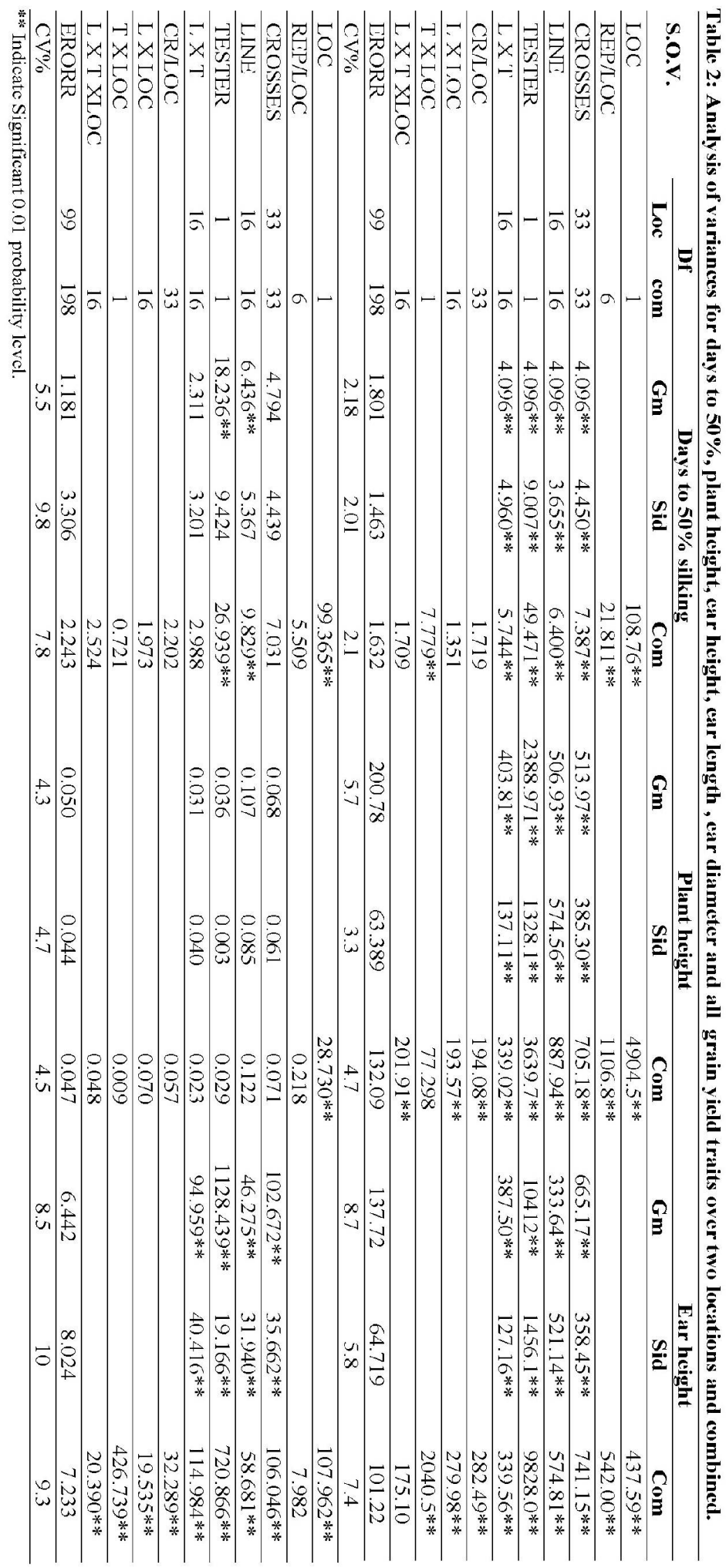




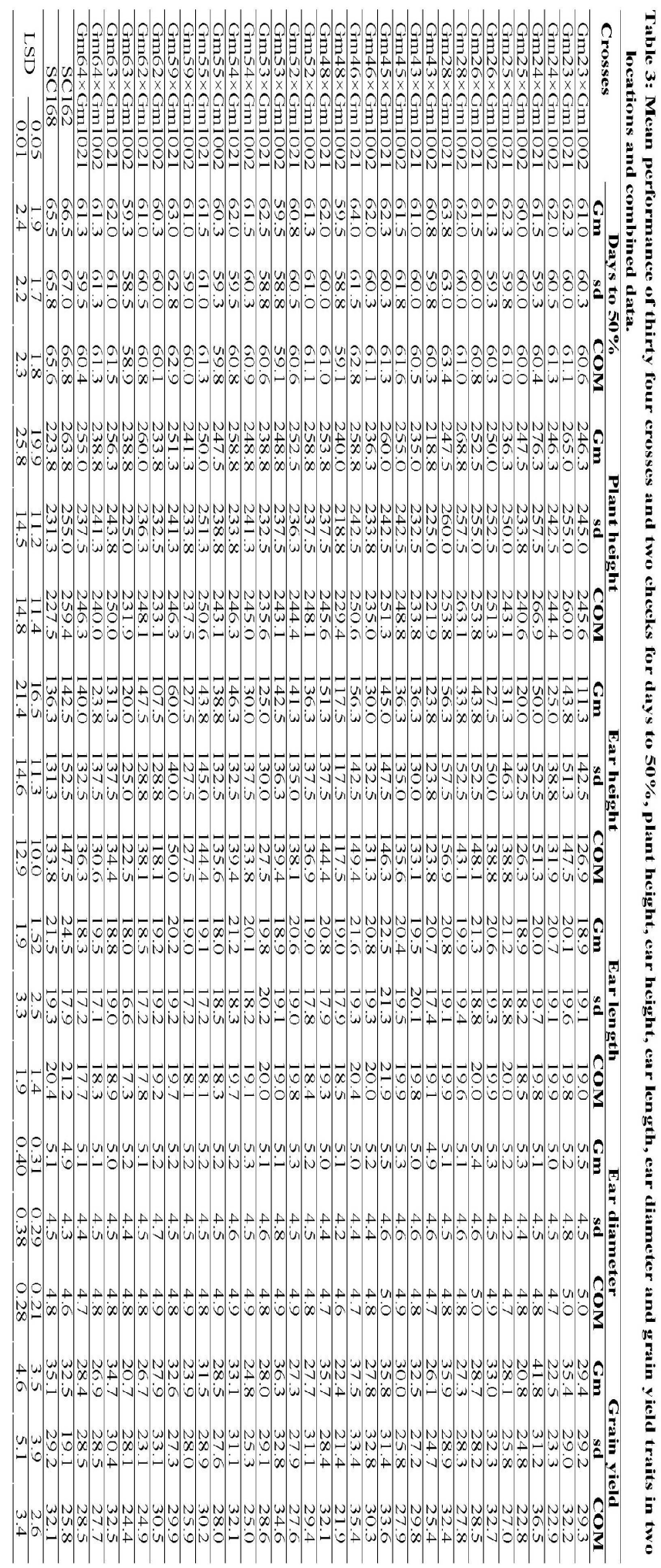




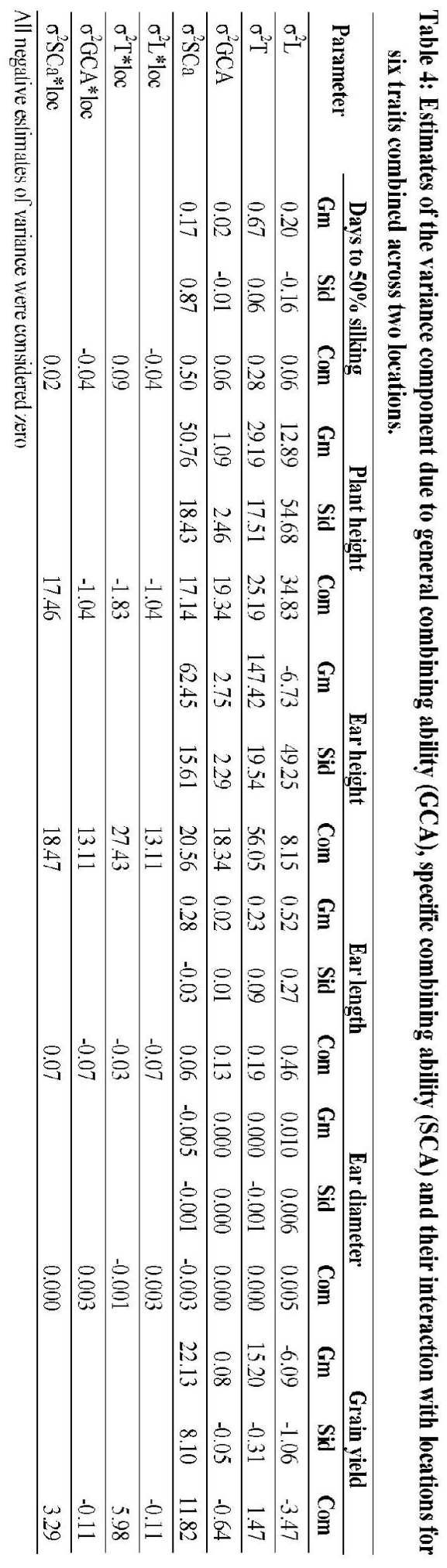




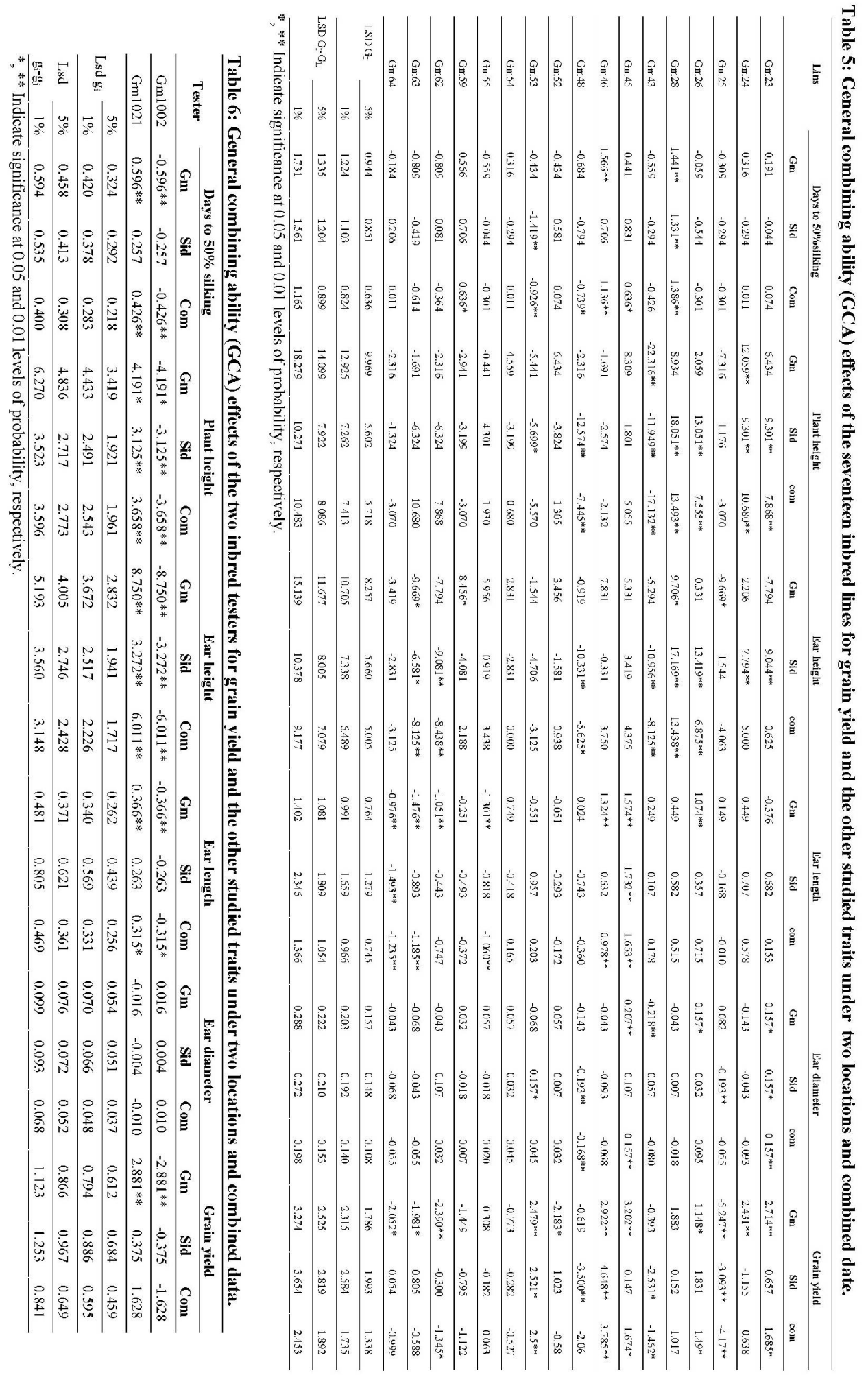




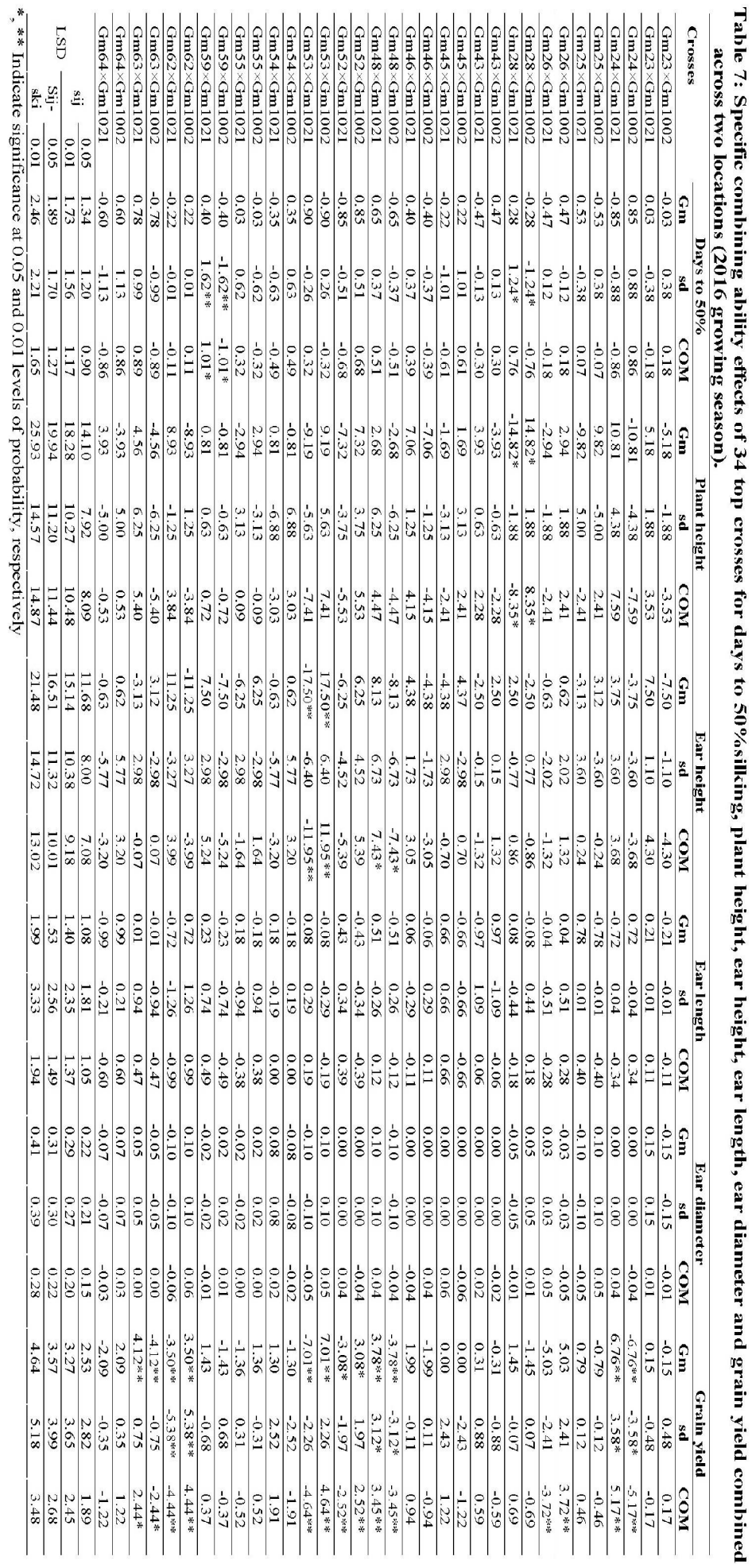




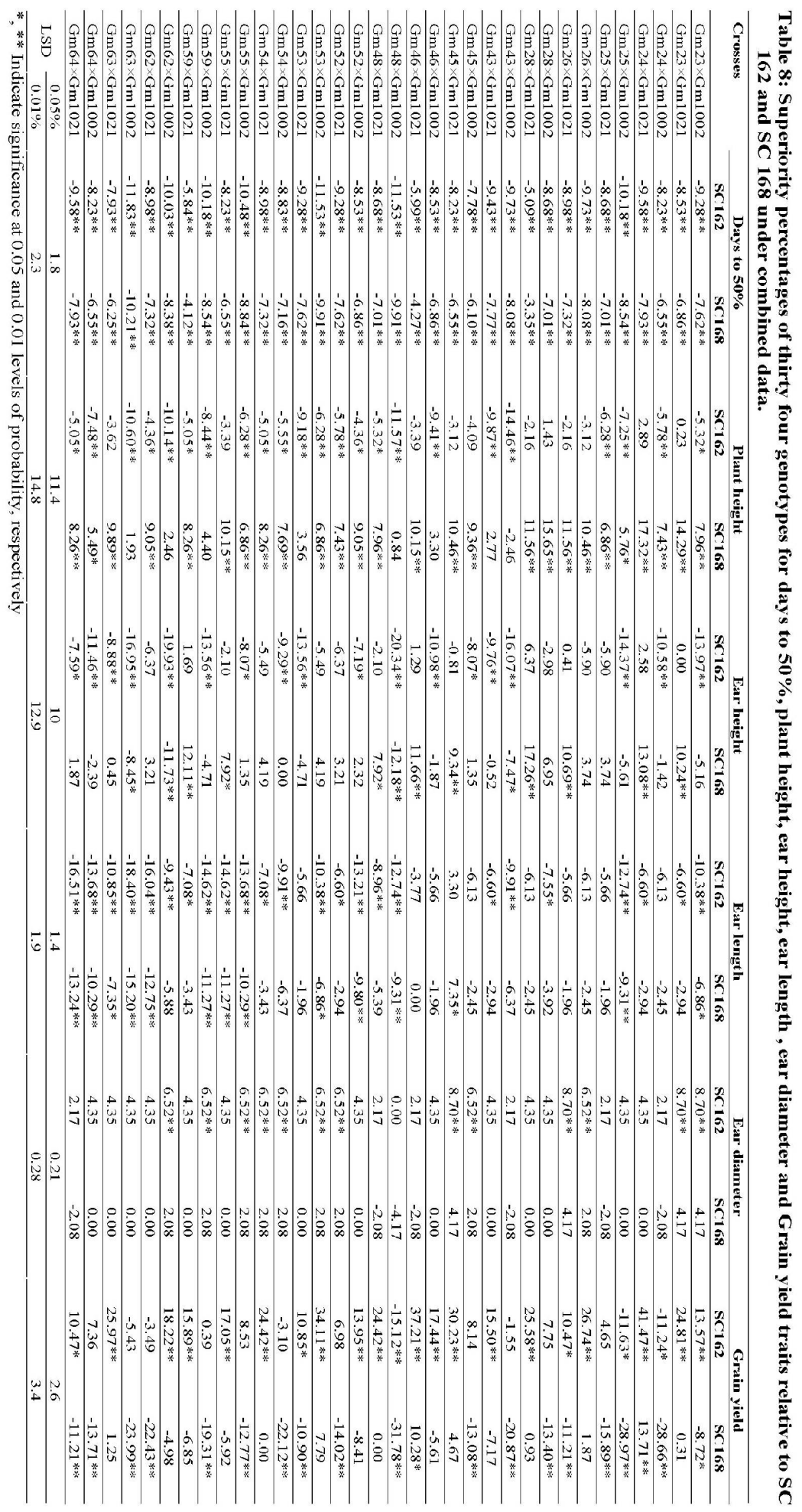


General combining ability effects $\left(\hat{g}^{\wedge}\right)$ :

Estimation of GCA effects for the seventeen yellow maize inbred lines were shown in Table (5). As for, days to $50 \%$ silking, the inbred line Gm53 had desirable negative and highly significant values for $\left(\mathrm{g}_{\mathrm{i}}\right)$ towards earliness. $\mathrm{Gm} 43$ at both locations and from combined data, Gm48 at Sids location and combined data and Gm53 at Sids location exhibited significant $\left(\mathrm{g}_{\mathrm{i}}\right)$ towards short plants.

Regarding ear height, at Gemmeiza two inbred lines (Gm25 and Gm63) and at Sids and from combined data, four inbred lines ( $\mathrm{Gm} 43, \mathrm{Gm} 48$, Gm62 and Gm63 ), had negative (desirable) and significant $\left(\mathrm{g}_{\mathrm{i}}\right)$ effects towards lower ear placement. For ear length, Gm45 at the two locations and combined data, Gm46 at Gemmeiza and combined data and Gm26 at Gemmeiza showed positive desirable and highly significant $(g \wedge i)$ effects for this traits. Concerning ear diameter, $\mathrm{Gm} 23$ at the two locations and combined data, Gm45 at Gemmeiza and combined data, Gm26 at Gemmeiza and Gm53 at Sids showed significant $\left(g^{\wedge} i\right)$ effects for this traits.

Grain yield data showed that, two inbred lines: (Gm46 and Gm53) under the two locations and combined data, two inbred lines: (Gm23 and Gm45) at Gemmeiza and combined data and one inbred line: (Gm24) at Gemmeiza had desirable significant positive $\left(g^{\wedge} \mathrm{i}\right)$ effects for grain yield.

Testers:

The inbred tester Gm1002 had desirable and significant values of $\left(\mathrm{g}_{\mathrm{i}}\right)$ effects for days to $50 \%$ silking, plant and ear heights, while, the tester Gm1021 showed positive and significant values of $\left(\mathrm{g}_{\mathrm{i}}\right)$ effects for ear length and grain yield at Gemmeiza and combined data (Table 6).

Specific combining ability effects $\left(\hat{s}{ }_{\mathrm{ij}}\right)$ :

Results in Table 7 showed that, days to $50 \%$ silking showed one cross (Gm28 x Gm1002) at Sids and one cross at Sids and combined data (Gm59 x Gm 1002) had negative and significant $\left(\mathrm{s}_{\mathrm{ij}}\right)$ effects for earliness. As for plant height, cross ( $\mathrm{Gm} 28 \times \mathrm{Gm}$ 1002) had negative and significant $\left(\mathrm{s}_{\mathrm{ij}}\right)$ effects at Gemmeiza and in combined date. Regarding ear height, results revealed that, crosses (Gm48 x Gm 1002) and (Gm53 x Gm 1021) had negative and significant $\left(\hat{s}_{\mathrm{ij}}\right)$ at Gemmeiza and in combined data. Depending on grain yield, three crosses (Gm24 x Gm 1021), (Gm48 x Gm 1021) and (Gm62 x Gm 1002) had positive and significant $\left(\hat{s}_{\mathrm{ij}}\right)$ effects at both locations and their combined data, while, two crosses; (Gm53 x Gm 1002) and (Gm63 x Gm 1021) at Gemmeiza and from combined data and also the cross (Gm26 x Gm 1002) in combined data had significant $\left(\mathrm{s}_{\mathrm{ij}}\right)$ for this trait.

Superiority percentages:

Superiority percentages relative to the two checks; SC162 and SC168 for the $34 \mathrm{~F}_{1}$ crosses from combined data were presented in (Table 8). It was noted that, negative values might be desired for no. of days to $50 \%$ silking, plant and ear heights, while the positive values would be favored for the other studied traits. Data showed that, all crosses had highly significant superiority for earliness over checks SC 162 and SC 168. 22 crosses had significant and negative superiority percentage in plant height over check SC 162. Out of the 34 crosses, 18 and 4 crosses had negative significant superiority percentages for low ear placement than check hybrids SC 162 and SC 168, respectively. Ear length results revealed that, one cross (Gm45 x Gm1021) had significant superiority percentage, over check SC 168. As for, ear diameter, 13 crosses had positive and significant superiority percentage, over check SC 162.

Concerning grain yield, data in Table 8 cleared that, relative to SC 162, 19 crosses had significant superiority percentage, while, relative to SC 168 only two crosses, i.e. Gm 24x Gm 1021 (13.71\%) and $\mathrm{Gm}$ 46x Gm 1021 (10.28\%).

\section{REFERENCES}

Aboyousef, H.A., H.A.A. Gamea and Moshera S.E. Sadek (2016). Evaluation of some new white maize top crosses for yield and some other traits. Alex. J. Agric. Sci. 61 (4): 409 - 418.

Aly R.S.H. (2013). Relationship between combining ability of grain yield and yield components for some newly yellow maize inbred lines via line $\times$ tester analysis. Alex. J. Agric. Res. 58(2): 115-124.

Aly, R.S.H., E.M.R. Metwali and S.Th.M. Mousa (2011). Combining ability of maize (Zea mays L.) inbred lines for grain yield and some agronomic traits using top cross mating design. Glob. J. Mole. Sci. 6(1): 01-08.

Barakat, A.A., M.A. Abd El-Moula and A.A. Ahmed (2003). Combining ability for maize grain yield and its attributes under different environments. Assiut J. Agric. Sci. 34(3): 1525.

Darwich, M.M.B.; Maha G. Balbaa and H.A. Aboyousef (2016). Evaluation of combining ability and type of gene action for grain yield and some related traits in some new yellow inbred lines of maize (Zea mays L.) using topcross. Egypt. J. P. Breed. 20 (4):700 -715.

El-Badawy, M. E. M. (2013). Heterosis and combining ability in maize using diallel crosses among seven new inbred Lines. Asian J Crop Sci. 5(1): 1-13.

EL-Hosary A.A.A., A.A. Elgammaal (2013). Utilization of line $\times$ tester model for evaluating the combining ability of some new white maize inbred lines. Egypt J. P1. Breed. 17(1): 79-72. 
Gamea, H.A.A., M.A.M. EL-Ghonemy and H.A. Aboyousef (2015). Analysis of combining ability in new yellow maize inbred lines (Zea mays L.). Egypt. J. Appl. Sci., 30 (1) 65 - 76.

Ibrahim, M.H.A, M.M.A. Osman and M.A. ElGhonemy (2007). Combining ability of new yellow maize inbred lines under two different locations. Minufiya J. Agric. Res., 32 (1) 185 201.

Irshad-El-Haq M.S.U, Ajmal, M. Munir and M. Gulfaraz (2010). Gene action studies of different quantitative traits in maize. Pak. J. Bot. 42: 1021-1030.

Kamara, M.M. (2012). Heterosis, combining ability and molecular studies on maize breeding. Ph.D. Thesis, Fac. Agric. Kafr El-Sheikh Univ., Egypt.

Kempthorne, O. (1957). An Introduction to Statistical Genetic. John Wily \& sons Inc., New York, USA.
Mosa H.E., A.A. Motawei and A.A. El-Shenawy (2009). Selecting a new single crosses of maize for grain yield and resistance to downy mildew disease under different locations and potassium fertilization. J Agric. Res. Kafr El-Sheikh Univ. 35(2): 522-536.

Mosa, H.E (2010). Estimation of combining ability of maize inbred lines using two cross mating designs. J. Agric. Res. Kafr EL-Sheikh Univ., 36(1):1-14.

Mousa, S.Th.M. and R.S.H. Aly (2012). Estimation of combining ability effects of new white maize inbred lines (Zea mays, L.) via line $\mathrm{x}$ tester analysis. Fourth Field Crops Conference "Field Crops Facing Future Challenges", Egypt. J. Agric. Res., 90(4): 77-90

Paul K.K. and Debanth, S.C. (1999). Combining ability analysis in maize. Pakistan J. Sci. Res. 42: 141-144.

Sadek, S.E., M.S.M. Soliman and A.A. Barakat (2001). Evaluation of newly developed maize lines using commercial inbred testers. Egypt. J. Appl. Sci.16:406-425.

Singh, P.k. and A.K. Roy (2007). Diallel analysis of inbred lines in maize (Zea mays, L.). Int. J. Agric. Sci. 3(1):213-216. 


\title{
الملخص العربي
}

\section{تقدير نسبة التفوق والقدرة على التآلف لصفة محصول الحبوب وبعض الصفات الأخرى في الأرة الثامية الصفراء}

\author{
هشام عبدالحميد أبويوسف \\ قسم بحوث الذرة الثنامية - معهد بحوث المحاصيل الحقلية - مركز البحوث الزر اعية
}

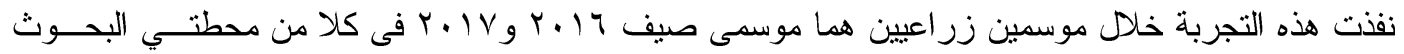

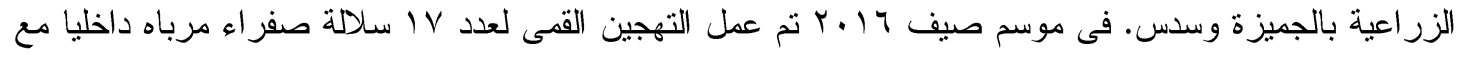

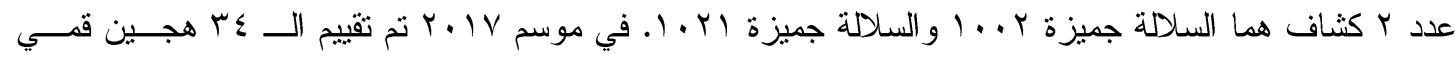

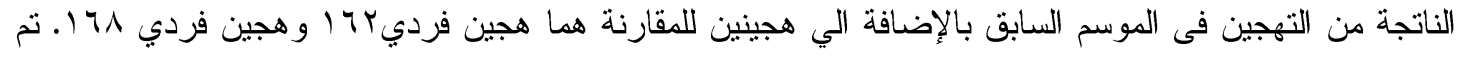

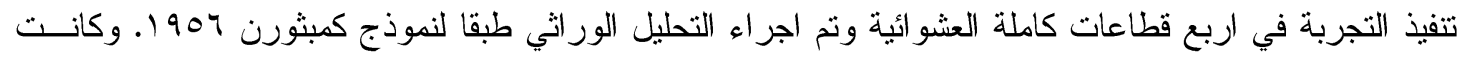

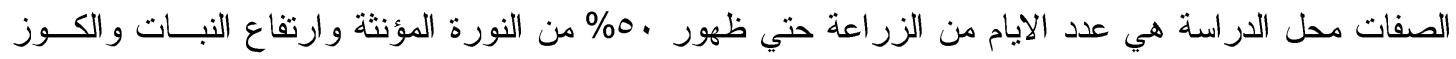

$$
\text { ويمكن تلخيص النتائج علي النحو التالي: ومحول الحبوب(اردب /فدان). }
$$

I. تحليل التباين الراجع إلى المو اقع عالي المعنوية لجميع الصفات محل الدئ الدراسة.

r. كان الفعل الجيني المضيف له دور مهم في وراثة صفات ارتفاع النبات وقطر الكوز وذللك في التحليل التجميعسي لئسي

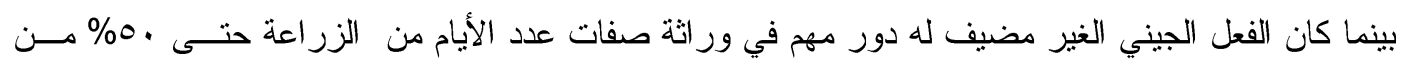

$$
\text { النورة المؤنثة وارتفاع الكوز وقطر الكوز ومحصول الحبوب (اردب للفدان). }
$$

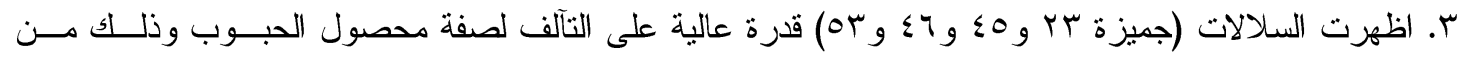

$$
\text { التحليل التجميعي. }
$$

ك. أعطت الهجن (Gm 24 x Gm 1021) و (Gm 46 x Gm 1021) قيما اعلى في محصول الحبوب و التبكيــر مقارنـــة

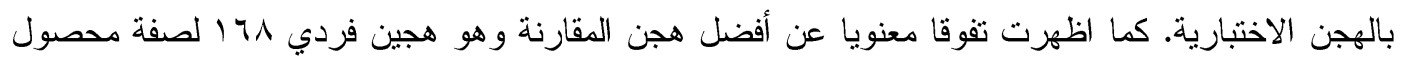
الحبوب و التبكير وكذلك قدرة خاصة علي التالف لصفة محصول الحبوب. 